\title{
Transatlantica
}

Revue d'études américaines. American Studies Journal

\section{Admirable Alterity on the Frontier: French Women's Agency in the Hollywood Western (1931-1980)}

Lara Cox

\section{CpenEdition}

\section{Journals}

Electronic version

URL: https://journals.openedition.org/transatlantica/15812

DOI: $10.4000 /$ transatlantica. 15812

ISSN: 1765-2766

Publisher

Association française d'Etudes Américaines (AFEA)

Electronic reference

Lara Cox, "Admirable Alterity on the Frontier: French Women's Agency in the Hollywood Western (1931-1980)", Transatlantica [Online], 1 | 2020, Online since 01 December 2020, connection on 01 February 2023. URL: http://journals.openedition.org/transatlantica/15812 ; DOI: https://doi.org/ 10.4000/transatlantica.15812

This text was automatically generated on 1 February 2023

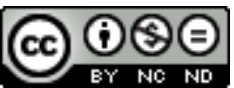

Creative Commons - Attribution-NonCommercial-NoDerivatives 4.0 International - CC BY-NC-ND 4.0 https://creativecommons.org/licenses/by-nc-nd/4.0/ 


\title{
Admirable Alterity on the Frontier: French Women's Agency in the Hollywood Western (1931-1980)
}

\author{
Lara Cox
}

Acknowledgements: I am grateful to James Stilley for his expertise on the sumptuous rug of Cimarron, and to Siham Bel, whose insight into the commercial workings of the film industry have been invaluable.

1 In February 2020, Le Monde film reviewer Mathieu Macheret remarked that David Perrault's Western Savage State (L'État sauvage, 2019) was refreshing and novel. As Macheret observes, Savage State tells of the under-recognized history ("l'histoire trop méconnue") of the French presence on the US Western frontier. The film depicts a French merchant family fleeing the Civil War after a raid by the Unionist army in their Missouri home. It gives a glimpse into both real-life French settlements in the state (e.g. Stepenoff 2006), and the precarious position in which French families found themselves with both Southern secessionists and Northern soldiers in the US following the proclamation of French neutrality by Napoleon III's government in 1861 (Sainlaude 77). For Macheret, what makes Savage State even more remarkable is that it is a "surprising feminist Western" ("un surprenant western féministe"), which centers on the arc of the French female characters over the male hero. The male mercenary Victor (played by Kevin Janssens) promises to deliver the French family to safety but abandons his post when it seems that death by a bloodthirsty and money-hungry gang of Southern rebels is inevitable. The Frenchwomen are left to shoot the proverbial baddies, which they do successfully.

2 The Canadian and French co-production Savage State seems to confirm the dual idea in recent Western scholarship that European influences (Broughton 2016) and the feminist-conscious twenty-first century (Delanöe-Brun 2018) are two major factors conditioning the contemporary Western's gender progressiveness. Yet Savage State is not the first example of a Western featuring a Frenchwoman with some degree of agency; indeed, looking at a corpus spanning five decades of the Hollywood Western 
(1931-1980), it is possible to see Frenchwomen consistently figuring in agentic ways. These women do not look like radical feminist warriors. As film producer Toscan du Plantier stated, Frenchwomen have often been cast in Hollywood films "because the Americans want to see them take their clothes off" (qtd. in Riding 11). Frenchwomen's sexual appeal is a prominent trait of the Westerns analyzed in this article. However, their sexuality is also their power, earning them an equal partnership with American male heroes who habitually triumph alone in the Hollywood Western (Cawelti 3). I favor the term "agency" here defined by Judith Butler as the capacity for individual action in a context of "subjection" to constraints (Butler 2). Thus, Frenchwomen's resistance to sexist scripts or their empowerment is in constant negotiation with male desire and design, which remain nonetheless prominent prerogatives of the Hollywood Western (Cawelti 153).

The article is organized in three parts. First, it sketches the forms of agency-not only sexual, but also economic and political-that Frenchwomen are endowed with over the five-decade period between 1931 and 1980. In the second part, I discuss that it is only after 1950 that the practice of casting Frenchwomen in leading roles in Westerns emerged as a distinct pattern in Hollywood. The commercial success of films such as An American in Paris (MGM, Vincente Minnelli, 1951) likely influenced the emergence of the "Frenchness Western." I adapt this term from Vanessa Schwartz's work on "Frenchness films" of the fifties and sixties, which foregrounded Paris and France (particularly of the Belle Époque) as havens of culture and glamor. "Frenchness Westerns" similarly marshal ideas about French high culture to represent Gallic women. This works in the service of these women: they are empowered beings who consistently outdo the American male heroes of these films. The third part of the article explains how this can operate favorably for Mexican and indigenous women. Concentrating on the fifties and sixties, I discuss how Frenchwomen-Catholic, sexually active, non-WASP-are often compared to Mexican and indigenous women. It is important not to forget a hierarchy in which pale-skinned Frenchwomen prevail over darker skinned American women in both US society and its mainstream film culture. My claim in this final part is thus tentative: Frenchwomen's status is that of an "admirable Other" for Americans, and this enables the possibility of sustained forms of interracial marriage, otherwise disallowed in the genre of the Hollywood Western (Delanöe-Brun 132).

The corpus studied here, though inevitably inexhaustive, contains all the films of the sound era in Hollywood that (to my knowledge) have cast Frenchwomen in leading roles, starting with Fighting Caravans in 1931 and ending with Heaven's Gate (1980). The latter film's commercial failure likely sounded the death knell for the Frenchwoman in the Hollywood Western, providing a natural end date to the corpus. One of the key focuses of this article is the explosion of American Francophilia on the Hollywood screen during the 1950s, which occasioned depictions of Frenchwomen in the Western as having agency. To show how this attitude was a shift from previous decades, I evoke Westerns of the thirties and forties. It will be up to future articles to contemplate, for example, the Frenchwoman in the Westerns of the silent era, such as Renée Adorée, who starred in Tide of Empire (MGM, Allan Dwan, 1929).

5 As part of Franco-American film history, this article makes a twofold intervention in recent scholarship on the Hollywood Western. It develops from a growing body of literature that has considered the US frontier as an "intercultural" space (Schulze et al. 2012; Miller \& Van Riper 2013; Broughton 2016; Burns \& Cabau 2017; Burns 2018). 
Gregory Mohr (2012) and Emily Burns (2018), in their studies of the "Camargue Westerns" and wild west shows at the Exposition Universelle of 1900, for instance, have discussed how friendships between the French and the Lakota Indians created opportunities for Native American self-representation, a degree of agency and authenticity disallowed in the United States. I turn to how Frenchness has been conceived from within American national parameters; this article reveals that Hollywood did not always represent foreignness in a reductive manner, and indeed, that French specificity has served as a way of representing emerging forms of feminist consciousness. The article also contributes to a nascent corpus in film studies that disputes earlier claims of the Western genre's misogyny and masculinism, most recently questioned by Mark Wildermuth (2018). Wildermuth shows that feminist themes are endemic to the Hollywood Western throughout the twentieth century from Cimarron (RKO, Wesley Ruggles, 1931) to The Quick and the Dead (TriStar, Sam Raimi, 1995). He suggests that Westerns index the social shifts of the twentieth century that progressively accorded women more power in the public sphere, from the end of the first wave of American feminism to the decades following the second wave of American feminism. While this critic analyzes French actress Denise Darcel's role in Westward the Women (MGM, Wellman, 1951), also considered here, he does not examine foreignness as an inflection on women's agency in the Western.

6 A note of caution should be sounded on two central terms in this article-the "Western" and "French"-since they are slippery, geographically speaking. A number of films, such as The Far Country (Universal, Mann, 1954), North West Mounted Police (Paramount, DeMille, 1940) (both taking place in Canada), and Vera Cruz (in Mexico) (United Artists, Aldrich, 1954), lie outside of the territory contained by the ninetyeighth meridian, the forty-ninth parallel, the Pacific Ocean and the border with Mexico used by some to delimit the West (Stegner 1992). The label "French" also loses territorial specificity. Characters may be defined ambiguously as hailing from an unnamed French-speaking "old country" (Cimarron 08:12) as is the case of the character of Sabra Cravat in Anthony Mann's remake of Cimarron (MGM, 1960); in other films it is unclear if they are French- or North-American born (as French Creoles from New Orleans or French Canadians). In others still, American women pass for French in order to make money from American men (as is the case for Frenchie [Universal, Louis King, 1950]). While acknowledging the geographical looseness with which I use the terms "Western" and "French," I echo historian Jay Gitlin's sentiment that a consideration of Frenchness on the frontier necessarily disrupts the geospatial coordinates of what we have commonly come to understand as the "western frontier" of the United States. Gitlin contends that a "Bourgeois frontier" existed in the nineteenth-century US, with French businessmen, fur traders, merchants, and families extending as far east as Illinois Country and Detroit, as far south as Louisiana and Mexico, and as far north as Canada. For Gitlin, this expanded frontier (developed according to French commercial interests) destabilizes romantic notions of the west being "won" by ordinary American cowboys and gunslingers. If, for Gitlin, Frenchness on the frontier connotes both geographical expansionism and the disturbance of commonly held beliefs about the West, in a parallel argument I suggest that the Frenchwoman in the Hollywood Western not only plays fast and loose with geographical fixity; she also defies the gendered, aesthetic, and racial assumptions at the heart of the Hollywood Western. She thus invites us to question the ideological certainties of what has become known as the “cinéma américain par excellence" (Rieupeyrout 1953). 


\section{The Economic, Political, and Sexual Agency of Frenchwomen on the Frontier}

7 From their beginning, mythologized recreations of the Western frontier (in dime novels, the Wild West shows, and so on) asserted a notion of the right type of foreigner, namely one of "Anglo-American old stock" (Bold 2). This was to the detriment of the French (among other nationalities), dismissed for their Catholic origins and Mediterranean temperament (Gitlin 5). Though French fur traders, such as those operating through the notable Chouteau emporium of Saint Louis, played a major role in the economic development of the frontier (Gitlin 2010), American historian Frederick Jackson Turner (1896) dismissed "[t]he gay, adaptable Frenchman" as too jovial and emotional to be a "wilderness conqueror" (397). Along with Francis Parkman, Turner effeminized Gallic masculinity in order to deem it extraneous to the history of the frontier and, thus, to the construction of the US (Gitlin 3).

8 Hollywood inherited the American myth of the Frenchman's incompetence on the frontier, and reproduced it in films such as The Big Sky (RKO, Howard Hawks, 1952) and Two Mules for Sister Sarah (Universal, Don Siegel, 1970). The Big Sky, the only Hollywood Western to deal in detail with the presence of French fur trappers (coureurs de bois) on the frontier (Havard 2016), casts the French as poor shots, incapable of warding off the threat of Indian invasion, and ill-adapted navigators who jeopardize the fur trapping mission by leading their boat up the powerful Missouri river at an inopportune time. Paradoxically, Frenchwomen in the Hollywood Western are not reduced to stereotypes: they tend to be wily, knowing actors on the frontier, displaying economic independence, political force of mind, and sexual power.

9 While in later decades prostitution becomes the main conduit to the Frenchwoman's financial autonomy in the Hollywood Western, having an eye for making money is a common character trait of French heroines in the Western including but not limited to the figure of the prostitute. The female lead of Fighting Caravans (Paramount, Brower and Burton, 1931) is an upwardly mobile emigrant woman Félice (Lili Damita) who has amassed a certain amount of wealth in her piggy bank but seeks more in traveling across the country to California, enriched by the 1849 Gold Rush. Félice is quite a contrast to the heroine of Zane Grey's 1929 story, the dependent, Anglo-American child, May Bell. The heroine of The Far Country, French-Canadian Renée Vallon (played by Corinne Calvet), progressively saves tiny amounts of gold dust which she procures by nudging the money-hungry American miners coming to weigh their gold in the local saloon-labelled the "sawdust concession" (The Far Country 23:49)-in Skagway. These savings put her in a position to marry and allow her to send her father overseas to complete his medical studies. In North to Alaska (Twentieth Century-Fox, Henry Hathaway, 1960), Monte Walsh (CCF, William Fraker, 1970), and Heaven's Gate (United Artists, Michael Cimino, 1980), the prostitute characters betray a reluctance to cede their independent income for love with an American hero. Ella Watson (Isabelle Huppert) in Heaven's Gate makes the unscrupulous declaration that she "like[s] money" more than she does her beau, Nate Champion, while carefully balancing the numbers in her accounting book for her Wyoming brothel (Heaven's Gate 01:10:43).

The Frenchwoman's ease with money in the Hollywood Western is, to a greater degree than the stereotyped accounts of the Frenchman on the frontier, a reflection of history. 
The transformation of Gray's May Bell to Félice was probably influenced by the presence of screenwriter Agnes Brand Leahy, one of the hundreds of women who found financial independence in the Hollywood system as a screenwriter during the twenties and thirties (Scharff 4). However, Félice is also a reflection of a number of nineteenthcentury Frenchwomen, who whether in French-speaking enclaves such as Sainte Geneviève (Missouri) or culturally mixed settings such as the California Gold Rush, amassed wealth in managing their husbands' financial interests, becoming independent landowners, or working in gambling saloons (Gitlin 388; Johnson 428; Stepenoff 112). Félice describes a practice of regularly "putting five pieces" (Fighting Caravans 57:59) in her piggy box since her childhood in preparation for marriage. This "custom with French people" (Fighting Caravans 58:03) resonates with the nineteenth-century Frenchwomen's continued application of the coutume de Paris in the US, which granted them equal rights to inherit property (Stepenoff 107).

11 Economically judicious, Frenchwomen are also often a force for democracy in Hollywood Westerns. The character of Renée Vallon (Corinne Calvet) in The Far Country (1954), as Jeanine Basinger writes, "represents part of a positive community of miners who eat together, sing and dance together, and support one another in times of stress" (99) in the Canadian border town of Dawson City. Indeed, Renée leads the community's resistance against crooked lawmaker Judge Gannon and saloon owner Ronda Castle, who cross the border from the US seeking to make a quick buck by cheating the miners out of their claims during the Klondike Gold Rush (1896-1899). In a saloon faceoff, Renée defiantly screws up Gannon's cross-file claim on her mine (The Far Country 01:22:23-01:22:55). The gesture is symbolic of the grievances felt by the men of the mining community, who group behind Renée in support, themselves victims of the same crime. Sporting trousers, a lumberjack shirt, and a beanie throughout the film, the heroine wears the garb of a French-Canadian man. She echoes the character of the trouser-wearing Vienna in Johnny Guitar (Republican Pictures, Ray), also released in 1954. Both characters may wear masculine attire but they eschew the use of physical force to settle territory disputes until no other means proves successful, reflecting the Cold War Western's ambivalent attitude to violence as a necessary evil (Corkin 2004). Renée, like Vienna, thus corresponds to a key element of the "feminist" western defined by Wildermuth (2018) in which values associated with womanhood-"love, compassion [...] domestic peace and security" (4)-are brought into the public space.

Other Hollywood Westerns of the Cold War period (1946-1962) (Corkin 2004) inflect women's political agency with French specificity. They do so by rehearsing France's republican idealism, which influenced the US's own revolution (Carter 2016). In The Jayhawkers! (Paramount, Melvin Frank, 1959), homesteader character Jeanne Dubois's very name evokes the coureurs de bois or French fur trappers on the frontier. Dubois embodies a French revolutionary spirit of the kind diametrically opposed to Napoléon, whose bust crowns the hideout of would-be dictator and gang leader of antebellum Kansas, Luke Darcey (Jeff Chandler). This Frenchwoman's belief in the ideals of democracy and equality feed into her distrust of Darcey who lures love interest Cam Bleeker (Fess Parker) into his fold. As she says of Darcey's promises to transform the state, loosely referencing Napoléon III's regime she left behind in France, "Oh I have heard that so often before [...] If you just hand over one little thing: your freedom, your dignity, your right to be a decent human being" (The Jayhawkers! 01:07:53). The film's final shot shows Cam and Jeanne walking hand-in-hand behind the corpse of the quasiNapoleonic Darcey (freshly killed by Cam); the camera dollies out to a high-angle view 
of the town, a visual metaphor that positions this transatlantic couple in a wider, historical frame, gesturing towards a symbolism of the triumphant commingling of French republican "freedom" and an American counterpart.

However, what is most recurrent in Hollywood Westerns featuring Frenchwomen is the sexual power they wield. American men repeatedly abandon their dreams of a solitary frontier lifestyle or even their political allegiances because of their desire for Frenchwomen (in Fighting Caravans, North West Mounted Police, Westward the Women, North to Alaska, Monte Walsh). In Fighting Caravans (1931), Félice evinces a sexuality powerful enough to make her marriage prospect, Clint Belmet, fall in line and renounce his job as a frontier scout despite his warnings to her: “I've always been free and I don't know if I'd like a woman to tell me this here and that there. I ain't never been tied down to nothing" (Fighting Caravans 59:40-59:49). Earlier in the film, Félice responds knowingly to a fellow female caravan member, who advises her to "honey [her man] and butter [him] on both sides": "I am French. I have known all what you say since I was so high" (Fighting Caravans 52:06-52:15).

An echo of West-Coast-bound emigrant Félice in Fighting Caravans, Fifi Danon (played by Denise Darcel) of William Wellman's Westward the Women (1951) is the main character in a posse of frontierswomen who cross the unforgiving American plains in order to find a new life and eager-to-marry men in California. As Wildermuth observes, it is Danon (a reformed prostitute) who "[a]mazingly [...] objectifies" (83) the male lead, Buck Wyatt (Robert Taylor). In a shot/reverse-shot sequence which positions the Frenchwoman as the subject of the gaze, Danon sees and covets Wyatt for the first time (Westward the Women 18:54-19:03), rejecting the photographs of the men on the wall that she has been told to choose from for a future husband. Danon twice remarks to Buck that he has a "beautiful face" (Westward the Women 01:13:44, 01:54:42)-a manifestation of active desire normatively expressed by men, which goes rewarded at the end of the film as the pair join the mass wedding party of newly arrived brides with their California beaus (Westward the Women 01:55:15). Ella Watson (Huppert) in Heaven's Gate, though ultimately killed by the henchmen of the Wyoming Stock Growers Association, also lives out her desire, this time for two lovers, Nate Champion and James Averill. Even though she refuses to choose between them, she earns the respect of both heroes (Cockeye 2019, 05:30).

It was not uncommon for the Hollywood Western to depict sexually active women through a prism of these women's foreignness. Indeed, Mexican women and Frenchwomen are often associated as sexual beings. However, Mexican women tend to be punished for the men they desire, unlike their Gallic counterparts. In My Darling Clementine (Fox, Ford, 1946), prostitute Chihuahua (Linda Darnell) is cast as neurotically jealous of other women (Cockeye, "Prostitution et cinéma", 02:33). Maria in The Professionals (1966) (played by star Claudia Cardinale) can only return to her child love, fellow Mexican rebel Raza (Jack Palance), after winning the approval and assistance of Anglo-American mercenaries (Burt Lancaster and Lee Marvin). Frenchwomen, on the other hand, are not deprived of agency because of their desire. In Westward the Women, Danon earns the respect of both men and women, getting her man and leading the other women in a move of solidarity of propping up a caravan while a fellow frontierswoman gives birth (Westward the Women 01:35:51-01:36:08).

Over five decades, the Frenchwoman's agency in the Western seems unchanging. However, with the exception of Fighting Caravans (1931), it was only during the 1950s 
that the presence of French actresses began to emerge as a pattern in the Hollywood Western. This pattern was part of a wider trend that heralded the influence of Francophilia on Hollywood cinema.

\section{Frenchness Westerns}

17 Frenchwomen starred repeatedly in Westerns as leading ladies to American cowboys and gunslingers during the heyday of Hollywood's "Frenchness films," a term that Franco-American film historian Vanessa Schwartz uses to describe musicals such as An American in Paris (Vincente Minelli, MGM, 1951), Gigi (Minelli, MGM, 1958), and Cancan (Walter Lang, Twentieth Century-Fox, 1960). As commercial aviation began and transatlantic tourism boomed in the wake of World War II, "Frenchness" films represented France on American cinema screens as glamorous and exciting. It hardly seems a coincidence that a number of French actresses, or women playing French characters, appeared in Westerns during this same period: Shelley Winters in Frenchie (1950); Corinne Calvet in The Far Country (1954) and Apache Uprising (1965); Denise Darcel in Westward the Women (1951) and Vera Cruz (1954); Nicole Maurey in The Jayhawkers! (1958); Capucine in North to Alaska (1960); Marie Schell in Cimarron (1960).

"Frenchness films" were promising commercial bets. In its first seven weeks at the Stillman Theatre in Cleveland (Ohio), An American in Paris generated over triple and a half the amount of normal box-office takings (Harris 104); Gigi earned back its expensive production costs and more after being awarded the prize of Best Picture at the Oscars (Monaco 155). Can-Can was the highest grossing film of 1960 ("All-Time Top Grossers" 69). Such lucrative "Frenchness films" seem likely to have given rise to a more modest sub-genre of the "Frenchness Western"-a term that I adapt from Schwartz to describe Hollywood Westerns in the 1950s and 1960s. This argument relies not on filmmakers' conscious acknowledgement of the influence of Frenchness films; rather Frenchness Westerns, like all mainstream filmmaking endeavors, were a business first and foremost. Commercially successful films create a "virtuous circle" ("cercle vertueux"), shaping what is created after them in similar genres. ${ }^{1}$ Concentrating on studio-era Hollywood productions, economic film historians John Sedgwick and Michael Pokorny point out that "life-cycle tendencies" form from "[h]ighly successful films, which "send back signals of audience preferences [...] to the originating studio and also its rivals." This results in "clusters of films with similar stories and aesthetic characteristics, forming, over time" (15, my emphasis). It is therefore my conviction that "Frenchness Westerns" were a "cluster of films" (Sedgwick and Pokorny 15) that borrowed visual patterns from Hollywood's Frenchness films.

19 A number of Franco-American visual studies specialists have written of Americans' long-held esteem for French glamor and luxury (Essif 2013, Mazdon 2000, Schwartz 2007), making "Frenchness films" part of a wider history of US Francophilia. Indeed, between 1930 and 1950, Hollywood remade an impressive tally of nineteen French films (Mazdon 13), five of which retained their original setting in Paris (One Rainy Afternoon [1936], The Lady in Question [1940], I Was an Adventuress [1940], Heartbeat [1946], The Man on the Eiffel Tower [1947]) (Mazdon 152-153). Early Westerns also represented France as a country of refined tastes. The cosmopolitan Frenchwoman Félice (Damita) in Fighting Caravans (1931) eventually persuades Clint Belmet (Gary Cooper) to leave the frontier. 
However, the battle between this French woman and her American man is not so clearcut. Félice (Damita) wistfully contemplates a married life with Clint (Cooper) in which wine, white tablecloths and serviettes adorn the dinner table each night; Clint scoffs at Félice's wish to tie "napkins around [his] neck like a baby" (Fighting Caravans 58:10-59:41), deeming it antithetical to the humble but honest living conditions of the American cowboy. Hollywood's ambivalence to France only intensified with the onset of World War II. The Gallicized character of Louvette in Cecil B. DeMille's hybrid Western North West Mounted Police (1940) (more on this film in the third part) is cast as a double-crossing siren. She has been considered by film studies specialists a cipher of French collaboration with Nazi Germany during World War II (Aleiss 67).

But by the fifties this ambivalence had ebbed and Hollywood's admiration for everything Gallic came home to roost. It is noteworthy that in the Westerns of this time, Frenchwomen were much more present than Frenchmen, with the exception of The Big Sky and Across the Wide Missouri (both Howard Hawks, 1951 and 1952 respectively). Systematically cast as leading ladies to American men, these women would seem to be the subject of a symbolic battle between the genders that was coded in national terms too. However, neither these women nor France fit a clichéd pattern of being the "weaker," because feminized, party. They were ideological matches to American men, as is demonstrated by shared revolutionary convictions in The Jayhawkers! Sometimes, they even surpassed men in numerous ways. For example, Frenchie (Universal, Louis King, 1950) remade the wily but ambiguously foreign "Frenchy" of Destry Rides Again (Marlene Dietrich) (Universal, George Marshall, 1939) into a sharp-minded businesswoman with a Gallicized edge. The eponymous heroine of Frenchie feigns the nationality and accent of her adoptive French family from New Orleans to attract American customers to her saloon. Frenchie (Shelley Winters) pokes fun at the credulous "pigeons" (North American slang for a gullible person) who "go for the gay Paree stuff" (Frenchie 29:00). Women performing French culture triumph repeatedly over American men in this film. Sheriff Tom Banning (McCrea) credits his disarming of the film's villain Lambert to a trick once taught to him by a can-can dancer.

The allusion to the can-can in Frenchie conjures up Paris during the Belle Époque (c. 1880s-1910), mythologized as an age of insouciance, cabaret, and "gay Paree"-the moniker Frenchie uses to advertise her saloon. Paris at the turn of twentieth century was similarly a staple of "Frenchness" films. Vincente Minnelli cinematographically brought to life the paintings of Belle Époque observer Henri de Toulouse-Lautrec (1864-1901) in a modern 1950s setting in An American in Paris (Dalle Vacche 13-42, Schwartz 38), while Gigi (1958) and Can-can (1960) were set at the turn of the century. The Moulin Rouge, Montmartre, and the Bois de Boulogne connoted a joie de vivre that enticed the post-war consumerist society in America, while Hollywood's selfassociation with the "'high culture' of French painting, literature, and luxury goods" of the Belle Époque allowed it to ward off criticisms of low-quality, mass entertainment (Schwartz 21).

22 Frenchness Westerns display similar traces of nineteenth-century French culture, which acts as a transformative force on the frontier. North to Alaska (Henry Hathaway, 1960), about the Nome Gold Rush (1899-1909), features actress Capucine in the role of French prostitute and cancan dancer Michelle Bonet whose love interest is miner Sam McCord (John Wayne). The film was released in the same year (1960) and by the same 
studio (Twentieth Century-Fox) as Cole Porter's musical set in Belle Époque Paris, Cancan (directed by Walter Lang, starring Shirley MacLaine as dancer and Frank Sinatra as love interest). With a poster reading "Cancan Girls Direct From Paris!" and a French accordion (North to Alaska 18:58) this Western stirs up similar associations with the turn-of-the-century world of cabaret depicted in Cancan. Moreover, in her first scene, Bonet is dressed in an off-the-shoulder red silk dress, recalling earlier incarnations of cabaret women known to Hollywood. Nine years earlier, United Artists financed John Huston's British-produced Moulin Rouge (1952); the studio's theatrical poster showed Belle Époque cabaret dancer Jane Avril (played by Zsa Zsa Gabor) in a revealing fulllength red dress. ${ }^{2}$ Though Capucine figures in this dress just once, the theatrical poster for the film shows the French star in crimson hues three times, perhaps aiming to reproduce the earlier visuals of Moulin Rouge-qualified as one of "Top Ten Box Office Hits of 1952" (Rowan 182). ${ }^{3}$

Bonet's casting in North to Alaska rejuvenated the Hollywood Western at a time when the genre was entering a more self-reflexive phase. According to New York Times reviewers Bosley Crowther and Eugene Archer (1960), Michelle Bonet (Capucine) was a much-appreciated addition to a film that had a "refreshingly mocking attitude" to the Old West (Crowther and Archer 36). Capucine's character outwits miners Sam McCord (John Wayne), and George and Billy Pratt (Stewart Granger and Fabian) by revealing the identity of McCord's (Wayne's) mysterious mining cross-claimant: the saloon owner Frankie Canon (Ernie Kovacs). She derives her agency from showing up the men of this film, both as a wily detective and a figure of desire for the "sex-starved trio" (Crowther and Archer 36) of miners. By ridiculing its men, North to Alaska aligns with the other "cynical comedies" of sixties "dystopian western" (Lusted 13), such as Cat Ballou (Columbia Pictures, Elliot Silverstein, 1965) and Waterhole 3 (Paramount, William Graham, 1967). By using a Frenchwoman to do so, the film tailored itself to an audience of cinemagoers that was becoming more youthful and cosmopolitan, rejecting older clichés and welcoming representations of "the Western hero [as] no longer taken seriously" (Lusted 521).

Borrowing from "Frenchness films" that had marketed Gallic culture with success, "Frenchness Westerns" may be understood as a strategy to revivify the genre for a market of cinemagoers who were increasingly skeptical about the myths of the American West (Carter 2010, 362). The trend extends beyond the fifties and sixties, the period covered by Schwartz in her research on the popularity of "Frenchness films." The Western Monte Walsh (1970) figures French New Wave darling Jeanne Moreau similarly to Capucine in North to Alaska as a superior Gallic presence in a world of hopeless men. Moreau was what New York Times reviewer Vincent Canby (1970) described as a check on the "comic mannerisms" (61) of the film's leading role, Monte Walsh (Lee Marvin). In one scene, an ageing Monte plays a risible Buffalo Bill, as he mounts a resting bronco in the dead of night just to prove to himself that he still has what it takes to control the steed, only to destroy half of the town buildings of Harmony, Arizona (Monte Walsh 1:03:12-1:08:33). Moreau plays the role of prostitute Martine Bernard. Unlike Monte, Martine is not given to ridiculousness or hyperbole. She shuns the label of "Countess" that Monte wistfully foists on her, chiding him, "Just because a woman is a foreigner doesn't make her a Countess." Monte responds with surprise ("hmm?"). Cast as more knowledgeable about worldly affairs, Martine highlights Monte's ignorance about romance too: while she would like to have dinner and talk with her suitor, Monte responds with the same interjection of 
incomprehension: "hmm?". He can barely disguise his haste to get her into bed (Monte Walsh 29:50-30:20).

A film about the threatened existence of the cowboy due to the arrival of the railroad, Monte Walsh is a seventies "elegiac western" (Lusted 573) that owed its success to Moreau, according to New York Times reviewer Canby (1970): “[i]t's an index of [Moreau's] screen personality that one welcomes her presence in the fading West without giving much thought as to how she got there" (61, my emphasis). The journalist implies that the Frenchwoman's presence on the frontier is inaccurate, which is symptomatic of lack of American knowledge about the history of the French on the frontier (Gitlin 10). Yet Moreau, like Capucine before her, is the opposite of the "fading West," hinting at a Francophile visual imaginary of Gallic glamor that Hollywood had conjured in earlier "Frenchness" films. Martine Bernard's very backstory is out of joint with the visual and historical imaginary of the American frontier, as she is tragically dying of tuberculosis. This was a much rarer disease in the American Far West than the "big killers [...] cholera, smallpox, and malaria" (Brown 128), and it wasn't a subject of concern for the Hollywood Western until Tombstone (Buena Vista, Cosmatos, 1993). By contrast, tuberculosis ravaged France and was the fodder of much nineteenth-century French Romantic literature and drama (Barnes 1995).

Inconsistent with generic codes of the Western, Monte Walsh may have found inspiration from Greta Garbo's role in George Cukor's 1936 film Camille, an adaptation of Dumas fils' 1851 La Dame aux camélias, which tells of the courtesan the Countess of Perregaux succumbing tragically to consumption. The publicity posters for Cukor's black-and-white film showed the heroine's hair as red, placing her in historical continuity with previous incarnations of the heroine, most notably by Belle Époque theatre star Sarah Bernhardt, who toured the American Far West starring in Camille between 1880 and $1881 .{ }^{4}$ Though before the period of "Frenchness films" of the fifties defined by Schwartz, Camille (MGM, Cukor, 1936) possibly inspired the aforementioned United Artists poster of Moulin Rouge (Huston, 1952), contributing to the decision to transform the blonde Zsa Zsa Gabor (playing Jane Avril) into a red-headed siren. Monte Walsh similarly dwells on Moreau's auburn hair; one scene even shows the hero mournfully cutting off a lock of his beloved's red locks as she lies dead (Monte Walsh 01:28:15-01:29:07). Monte's repeated nickname for prostitute Martine (Moreau) -"Countess"-would also seem an allusion to the courtesan Countess of Camille.

Perhaps Hollywood's fetish for red-headed Gallic prostitutes also explains Isabelle Huppert's role as brothel madam and cattle rustler Ella Watson in Heaven's Gate (United Artists, Michael Cimino, 1980), ${ }^{5}$ the last film (to my knowledge) to feature a Frenchwoman prominently in the American Western. Astonishingly adept on a horse, Ella Watson is also a possible inheritor of the Belle Époque horsewomen or écuyères who had already caught the attention of Hollywood. These daring female horse-riders gained agency-"horse agency" as Kari Weil puts it (343) - by performing feats of speed and acrobatic tricks on their horses in the cabarets, circuses, and the Bois de Boulogne of the turn of the century. Set in 1900, the musical Gigi showed écuyères in the Bois de Boulogne and in the cabarets as independent and fun-loving women (Gigi 00:00:33-00:04:52; 00:45:52); Moulin Rouge (Huston, 1952), financed by the same studio that produced Heaven's Gate (United Artists), also filmed the écuyeres, this time of the Parisian circuses, through the eyes of artist Toulouse-Lautrec. The film features the latter's best-known painting on the subject "At the Circus Fernando: the Circus Rider or 
Bareback Rider at the Circus Fernando" (1888) (Moulin Rouge 01:09:50-01:10:05, 01:20:08), which shows a ringmaster outrun by a woman in a tutu riding bareback and side-saddle; in a circus scene the film depicts the acrobatic female equestrians who inspire Toulouse-Lautrec's painting (Moulin Rouge 01:41:14).

As Schwartz suggests, Moulin Rouge was not Hollywood-produced, but it was financed by it-as one of the many "independent productions" backed by United Artists during the 1950s and 1960s that followed a "business model [...] [of] differentiating studios and their films [...] [and] building on cultural interests and tastes such as "Frenchness"' (Schwartz 47). United Artists had already entered the market of "Frenchness films" by the time it came to produce Heaven's Gate. Thus, for Cimino's western three decades later, it is possible to hypothesize at least some influence on Huston's film of this earlier commercial success. A scene in which Ella Watson (Huppert) escapes the bullets of the Wyoming Stockgrowers Association by leaping onto her horse from her buckboard (Heaven's Gate 02:19:10) seems to resonate with the "physical agility and bodily mastery" (Weil 435) of the écuyères seen in Moulin Rouge even if she does not exactly reproduce the latter's circus setting. Director Michael Cimino was also cognizant of the commercial viability of the Belle Époque aesthetic. His commercial for United Airlines in 1967 contained cancan kicking women in sixties mini dresses singing and dancing against the backdrop of an electric-bulb powered French flag, echoing the mix of modernity and the Belle Époque of hit musicals such as An American in Paris (1951) or Funny Face (Paramount, Donen, 1957).

In addition, when Ella (Huppert) embarks upon an equine joyride in another scene of Heaven's Gate, she may recall Toulouse-Lautrec's paintings of insouciant women during the Belle Époque in countryside outings at the helm of horse-drawn carriages. Ella lets out whoops of joy, ripping through the Wyoming countryside on a buckboard offered to her for her birthday by lover and sheriff Jim Averill (Heaven's Gate 53:00-53:30). This contrasts sharply with the close-ups of an apprehensive Jim gulping down his flask of whisky for reassurance, clamping his Stetson to his head with his palm, and telling his lover to "slow down." Similarly, in Toulouse-Lautrec's "La Comtesse Noire" (1881), "Country Outing" (1897), and "Double Harness Attelage en Tandem" (1897), women drive carriages that gather pace as male partners sit beside them with somber facial expressions or cautious, crossed arms.

Whether these are conscious or unconscious expressions of Belle Époque horse-women, their presence in the Hollywood Western are remarkable, since powerful and graceful steeds are typically an expression of the American male hero's potency (Hockenhull 175)-not the foreign woman's one. For example, in the gender progressive Two Mules for Sister Sara (Don Siegel, 1970), the eponymous Anglo-American heroine (played by Shirley MacLaine) trails behind her man (Clint Eastwood) (Two Mules 01:53:03) at the end of the film. Urging her animal on with her parasol, MacLaine, riding on a mule, is rather ludicrous alongside Eastwood, on horseback.

31 A commercial strategy of Heaven's Gate may have been to tap into a well-established market of Hollywood Frenchness films that United Artists had already encountered three decades earlier with Moulin Rouge. In any case, the film was a commercial failure. Heaven's Gate remains the most famous commercial flop in the history of Hollywood Westerns, the financial losses causing United Artists to be sold off to MGM (Carter 2010, 373). The catastrophic box office returns of Heaven's Gate help explain why (to my knowledge) Frenchwomen have not appeared in leading roles in Hollywood Westerns 
since 1980. In his 1986 book, Steven Bach, senior executive at United Artists during the making of Cimino's Western, retrospectively argued that Huppert did not sit well with American audiences-she was too "young", "contemporary," and "French" (191). A decade earlier, Jeanne Moreau's presence in Monte Walsh was welcomed even if it was (erroneously) judged anachronistic (Canby). With Heaven's Gate, Frenchwomen in the Western would become synonymous with bankruptcy.

Yet all the women in the Hollywood Western after 1950, Huppert included, outperform American men in a certain sense-either through their intelligence (Capucine's resolution of the mystery in North to Alaska; Moreau's worldly knowledge in Monte Walsh) or their thirst for danger (Huppert on her buckboard and horse in Heaven's Gate). Though they surpass men in the aforementioned respects, their relationship to other women proves quite different.

\section{Frenchwomen's Admired Alterity and Racial Difference in the Hollywood Western}

As mentioned previously, Frenchwomen can be compared to Mexican women in Hollywood Westerns insofar as both are depicted as sexual beings. In films such as Vera Cruz (1954) and Apache Uprising (Paramount, Springsteen, 1965), the stories of French and Mexican women are told simultaneously. In other films, such as North West Mounted Police (1940) and North to Alaska (1960), Frenchwomen are compared to Native American women. Even if they are not equivalent to indigenous or Mexican women, Frenchwomen are "darkened" on the American cinema screen. They are positioned in a similar vein to another Catholic nationality, the Irish, in what Charles Ramírez Berg, studying the films of John Ford, describes as "an ethnic margin" between white and non-white (Ramírez Berg 79-80). Yet Frenchwomen's "not quite" white status evolved over time.

During World War II, in the context of French collaboration with Nazi Germany, the hybrid Western adventure film North West Mounted Police (Paramount, De Mille, 1940) was released. It depicted a Gallicized woman character as an indigenous threat to the white Anglo-Saxon frontiersman. American actress Paulette Goddard, who would later star as "Frenchy" in the radio version of Destry Rides Again (1941), played the character of "Louvette," a name which bears traces of the French word for "she-wolf" (louve). Louvette is a member of the insurrectional Métis, an interracial community whose origins were French and Native American. Incarnating Frenchness, indigeneity, and animality (as a "louve"), Louvette seduces Anglo-Saxon Mountie Ronnie Logan and kidnaps him to prevent him from quelling her community's uprising; in a tragic case of mistaken identity (North West Mounted Police 01:48:56), she accidentally has Logan killed after she instructs a fellow Métis to shoot the Texas Ranger called in to aid the Mounties quell the rebellion, "Dusty Rivers" (Gary Cooper). Louvette is vilified-"partIndian," "all bad" as the film describes her (North West Mounted Police 30:57). The character confirms the Hollywood Western's harshly punitive treatment of mixed-race people. Irredeemably treacherous, these characters are judged loyal neither to whites nor to full-blooded First Nations communities. In North West Mounted Police full Indians are disturbingly shown as allied with the Anglo-Saxon colonizers against the Métis. Hollywood leveraged the part-French Métis Louvette to condemn France's surrender to 
Nazi Germany during the war, casting it as a question of Gallic racial inferiority to white Anglo-Saxons (Aleiss 8).

The women of the period of "Frenchness Westerns" discussed earlier (the 1950s and 1960s) represent racial difference somewhat more positively. Because they emerged from a context of Hollywood Francophilia, Frenchwomen of these films are admired at the same time that they may be racially othered. They embody an "admirable alterity" (my own term). To take an example, in her Nome hotel room, Michelle Bonet from North to Alaska (1960) visually complements the painting of a shapely and slim-waisted maiden of racially ambiguous origins who is nativized by the greenery that forms the painting's backdrop. In this and subsequent shots (North to Alaska 01:51:49-01:53:02), Bonet is also contrasted with the photograph of the white burlesque dancer or prostitute, whose corpulence does not resemble Bonet's svelte body.

In her work on Gold Rush California (1848-1855), historian Susan Lee Johnson posits that French, Mexican, Chilean, Spanish, and Miwok women mixed together in saloon and other settings, demonstrating a racial slipperiness that gave these women a relative degree of sexual capital and thus financial power over Anglo-American women, who arrived late to the scene. The "ugly, b[ro]ad-shapened specimen[s] of the puritans" described by the men in Johnson's account (Perkins qtd. in Johnson 431) recall the wide-girthed burlesque dancer marked out as so different from Bonet in the Alaskan Gold Rush setting of North to Alaska. The visual alliances in this film between French and nativized women are thus long-standing.

Hollywood Frenchness Westerns of the 1950s and 1960s revived, to some degree, this cross-racial female agency. The Frenchwoman's visual affinities with the indigenized maiden in North to Alaska in one sense reinforces Orientalist art histories that hinge on light-skinned women connoting exotic otherness (Yegenoglu 116). However, the halfnaked Bonet is not simply objectified in these shots: she also reveals the missing identity of would-be crook and claimant of her love interest Sam McCord's (Wayne's) mine, while John Wayne's facial expression, befuddled and confused, conveys his inability to keep up with the canny Frenchwoman. Bonet hardly gives voice to the silent indigenized woman captured in the picture who nonetheless remains secondary and in the background. However, it may at least be posited that she imbues the scene's depiction of exoticized sexuality with positive associations about women's intellect and agency.

In other words, sometimes Frenchwomen's "admired alterity" directly benefits the characterization of indigenous and Mexican women. In certain Frenchness Westerns, this even enables the representational possibility of interracial coupledom and marriage, which in the Hollywood Western has overwhelmingly been doomed to failure (Buscombe 118)-either because of white men's disinterest or ultimately favoring of a white bride (e.g. Buffalo Bill, Twentieth Century-Fox, Wellman, 1944), or the tragic death of indigenous brides and grooms (e.g. Broken Arrow, Twentieth Century-Fox, Daves, 1951).

In Vera Cruz (1954), Denise Darcel's role as French Countess Duvarre commingles with Mexican independence fighter Nina (Sara Montiel) to make the Mexican woman's interracial romance with Ben Trane (Gary Cooper) an eventuality. The plot revolves around the two women's competing ambitions: the Countess plans to abscond with the stash of the Second Mexican Empire, aided by mercenary and love interest Joe Erin (Burt Lancaster); Nina tries to procure these riches to help Mexican freedom fighters, 
the Juaristas, a cause to which she eventually reconciles the amorous Ben Trane (Cooper). Nina and Ben Trane ultimately triumph over the French Countess and Joe Erin. Erin is shot dead after a failed attempt to double-cross the French Countess and make off with the riches on his own. Yet the final scene supplants the expected final embrace between Ben Trane and Nina with an exchange of glances between the white male hero and the French Countess (Darcel), shot from the latter's perspective (Vera Cruz 01:32:23-01:32:29). Ben Trane doffs his Stetson to the Countess, bidding farewell to her and her scheming ways; then two separate shots show Nina and Ben Trane walking towards each other, their eyes and lips never meeting in a single frame (Vera Cruz 01:32:36-01:32:45). In other words, the camerawork implies cross-racial romance between the Mexican woman and her white male partner only via the suggestion that there is nothing between the white man and the French woman, Countess Duvarre.

By opposing the treacherous French Countess and the nobly intentioned Juarista Nina, Vera Cruz destabilizes the Hollywood Western's conventional dichotomy of white women's sexual-moral purity and racialized women's putative impurity (Slotkin 436). In High Noon (United Artists, Fred Zinnemann, 1952), Gary Cooper's character Will Kane favors white virgin and pacifist (Quaker) Amy (Grace Kelly), over former lover, Mexican prostitute, and ex-lover of the film's villain Frank Miller, Helen Ramirez (Katy Jurado). In Vera Cruz (1954), Cooper seemingly opts for the Mexican bride he had rejected in High Noon (1952), but it is crucial to note that the camera never films Cooper's union with the Mexican woman, visually privileging his exchange of glances with the French Countess. On the one hand, this hardly promotes the right of Mexican woman Nina (played in fact by Spanish actress Montiel) to love who she wants regardless of race. On the other hand, the scene enlists Frenchwomen's historical proximity to racial otherness-their "not quite" white female agency-to enable a Mexican woman to end happily with a white man, a possibility that had been foreclosed two years earlier in High Noon.

41 Similarly, whereas hopes of a union between Shoshone Indian Lance Poole and white lawyer Orrie Masters are dashed by Poole's death in Anthony Mann's Devil's Doorway (MGM, 1950), the director's remake of Cimarron ten years later brought the theme of interracial coupledom to a successful conclusion via the role of "French American" (AFI 245) Sabra Cravat. Edna Ferber's original story (published in 1930) and Wesley Ruggle's 1931 film adaptation (RKO) focus on Sabra's coming into her professional own as an Oklahoma Congresswoman (Wildermuth 27). By contrast, Mann's 1960 version grounds the character's evolution in the remediation of her racist beliefs about her superiority to the Oklahoma First Nations communities. In a scene that anticipates her change of heart, she is visually assimilated to the indigenous daughter-in-law, Ruby, above whom she believes herself to be. When Sabra's son Cimarron announces his marriage to Ruby, Sabra angrily rejects the couple and sits resignedly on the staircase of her luxurious Osage house (Cimarron 02:17:00), alone and having lost her only son. The staircase is covered in an expensive ornamental rug of resplendent red peacocks, whose "Aghstafa" design hails from the Caucasus of Central Asia (Stilley 2020). ${ }^{6}$ Originating from a region remote from the film's Oklahoma setting, the rug's prominent crimson avian motif nonetheless visually recalls the daughter-in-law that Sabra had just minutes before shunned: Ruby, whose full name is Ruby Red Feather (Mickie Chouteau). Sabra is literally denied the superior position she had carved herself vis-à-vis Ruby, the birds and the color red looming large over her, the white jabot of her Victorian dress appearing an insipid copy of the vibrant crimson triangular motif 
on the rug. Cimarron does not ultimately escape Hollywood clichés about "good" Indians' assimilation into white society (Buscombe 123); Ruby feeds stereotypes of the nobly silent Indian, who barely speaks and dresses in western clothes as she marries into the white family. However, the staircase scene constructs a slippage between French American women and indigenous culture to challenge beliefs about racial superiority.

\section{Conclusion}

Star of Westward the Women and Vera Cruz, Denise Darcel commented on her time in Hollywood: "In Paris, I am [...] glamorous [...] I come to Hollywood and I am a peasant!" (Fox 20). This article has proposed that Frenchwomen like Darcel who starred in Hollywood Westerns during the fifties and sixties far from lost their Gallicized glamor. The wound of World War II and Vichy had cooled America's enthusiasm for all things French, with North West Mounted Police (1940) confirming Hollywood's hostility to France and reversing a broadly positive attitude to Frenchwomen that can be seen in Fighting Caravans (1931). However, "glamor" is a staple of the Hollywood "Frenchness Western" post-dating 1950 that, indeed, empowers Frenchwomen. French heroines are "glamorous" because they conjure up the cancan, cabarets, and joie de vivre of Belle Époque France. Isabelle Huppert, for instance, recalls the acrobatic ecuyères roaming the parks and circuses of fin-de-siècle Paris as an alien entity to a genre of cinema known for affirming the agile feats of men on their steeds. Stars like Capucine, Jeanne Moreau, and Denise Darcel display a self-assured, intelligent sexuality admired by Americans precisely for its differences from preconceptions about pure white, AngloAmerican women. This sexual agency both rejuvenated the Hollywood Western in the genre's introspective decades (Moreau's rescuing of the hammy Monte Walsh, for instance) and was even used to enable racialized women in interracial coupledom (the Countess's promulgation of the love between Ben Trane and Nina in Vera Cruz; Sabra's demotion to a symbolic position below her daughter-in-law in her luxuriously carpeted staircase in Cimarron).

Yet Darcel's words also ring alarm bells. Her judgement that she had become a "peasant" encapsulates her downgraded position in Vera Cruz: Mexican Nina may have humble origins, but as a woman fighting for the independence of her country, she is more noble than the thieving and greedy Countess played by Darcel. "Peasant" is also a derogatory word that illustrates that the French or French-speaking actresses starring in Hollywood Westerns were no social justice warriors actively promoting the causes of women less privileged than themselves. My argument, in fact, has centered on aesthetic allusions to crossovers between French and indigenous or Mexican women that may aid the latter's cause-whether that be via an indigenized (but not actually First Nation) staircase rug in Cimarron, a painting of an indigenized maiden in North to Alaska, or the editing and camerawork at the end of Vera Cruz.

None of this replaces the still-urgent need for Hollywood to start producing films grounded explicitly in the stories of the many indigenous, Mexican, African-American and other non-white women who inhabited the American frontier. In the last three decades of Hollywood Westerns, white, Anglo-American women have emerged as the new empowered figure of the Hollywood Western. ${ }^{7}$ The filmic corpus in this article, pre-dating this Anglo-white trend, allows us to understand that, before this, the genre 
had put forth a form of women's agency that straddled the categories of "white" and "racially other" in the figure of the Frenchwoman. The stakes now are to return this agency to the indigenous, Mexican, and other non-white women who sorely deserve prominent representation in Hollywood's visual recreations of the American Far West.

\section{BIBLIOGRAPHY}

AFI (American Film Institute). Within Our Gates: Ethnicity in American Feature Films, 1911-1960. Ed. Alan Gevison. Berkeley: University of California Press, 1997.

“All-Time Top Grossers," Variety, January 8, 1964, p. 69.

ALEISS, Angela. Making the White Man's Indian: Native Americans and Hollywood Movies. Westport: Praeger, 2005.

BACH, Steven. Dream and Disaster in the Making of Heaven's Gate. London: Faber, 1986.

BARNES, David. The Making of a Social Disease: Tuberculosis in Nineteenth-Century France. Berkeley: University of California Press, 1995.

BASINGER, Jeanine. Anthony Mann. Middletown: Wesleyan Press, 2007.

BOLD, Christine. The Frontier Club: Popular Westerns and Cultural Power, 1880-1924. Oxford: Oxford University Press, 2013.

BROUGHTON, Lee. The Euro-Western: Reframing Gender, Race and the 'Other' in Film. London: I. B. Tauris. 2016.

BROWN, Dee. The Gentle Tamers: Women of the Old Wild West. Lincoln: University of Nebraska Press, 1981.

BURNS, Emily C., and Agathe Cabau. "Call and Answer: Dialoguing the American West in France," Transatlantica [Online], 2 | 2017. URL: journals.openedition.org/transatlantica/10676 ; DOI: doi.org/10.4000/transatlantica.10676. Accessed 2 September 2020.

BURNS, Emily. Transnational Frontiers: The American West in France. Norman, OK: University of Oklahoma Press, 2018.

BUSCOMBE, Edward. 'Injuns!' Native Americans in the Movies. Bodmin: Reaktion, 2006.

BUTLER, Judith. The Psychic Life of Power: Theories in Subjection. Stanford: Stanford University Press, 1997.

CANBY, Vincent. “Screen: The Drama of Monte Walsh.” New York Times, 8 October 1970, p. 61.

CARTER, David. The Western. E-book. Kamera Books, 2010.

CARTER, Kathryn. "The American Republic and the French Revolution". Common Place, vol. 16, no. 3, 2016. commonplace.online/article/the-american-republic-and-the-french-revolution/. Accessed September 2, 2020.

CAWELTI, John. The Six-Gun Mystique Sequel. Bowling Green, OH: Bowling Green State University Popular Press, 1999. 
COCKEYE, Sam. “"Prostitution et Cinéma': Femmes de Western.” Videodrome. 5 November 2019. www.youtube.com/watch?v=0ZjtbLxqlkM. Accessed 2 September 2020.

CORKIN, Stanley. Cowboys as Cold War Warriors: The Western and US History. Philadelphia: Temple University Press, 2004

CROWTHER, Bosley, and Eugene ARCHER. “North to Alaska." New York Times, 11 November 1960, p. 36

DALLE VACCHE, Angela. Cinema and Painting: How Art is Used in Film. Austin: University of Texas Press, 1996.

DELANOË-BRUN, Emmanuelle. "Brides in Red, White and Blue: The Politics of Marriage in Classical and Revisionist Westerns." Histoire, légende, imaginaire : Nouvelles études sur le western. Ebook. Ed. Jean-Loup Bourget et al. Paris: Presses de l'École normale supérieure, 2018, p. 129-139.

ESSIF, Lee. American 'Unculture' in French Drama: Homo Americanus and the Post-1960 French Resistance. Basingstoke: Palgrave, 2013.

FOX, Margalit. "Denise Darcel, 87, Actress of the 1940s and '50s," New York Times. 11 January 2012, p. 20.

GITLIN, Jay. Bourgeois Frontier: French Towns, French Traders, and American Expansion. New Haven: Yale University Press, 2010.

HALLET, Hilary. Go West, Young Women! The Rise of Early Hollywood. Berkeley: University of California Press, 2013.

HARRIS, Sue. An American in Paris. London: BFI, 2019.

HAVARD, Gilles. “L’Amérique oubliée des coureurs de bois." France Culture. 24 September 2016. www.franceculture.fr/emissions/tout-un-monde/lamerique-oubliee-des-coureurs-de-bois. Accessed 2 September 2020.

HOCKENHULL, Stella. "Horse Power: Equine Alliances in the Western". Love in Western Film and Television: Lonely Hearts and Happy Trails. Ed. Sue Matheson. New York: Palgrave, 2013.

JOHNSON, Susan Lee. Roaring Camp: The Social World of the California Gold Rush. New York: Norton, 2000.

LUSTED, David. The Western. London: Routledge, 2003.

MACHERET, Mathieu. “'L'État sauvage': un western français et féministe qui se joue des codes du genre.” Le Monde, 26 February, 2020. www.lemonde.fr/culture/article/2020/02/26/1-etatsauvage-un-western-francais-et-feministe-qui-se-joue-des-codes-du-genre_6030867_3246.html. Accessed 1 September 2020.

MAZDON, Lucy. Encore Hollywood: Remaking French Cinema. London: BFI, 2000.

MILLER, Cynthia, and A Bowdoin VAN RIPER, eds. International Westerns: Re-locating the Frontier. Lanham: Scarecrow Press, 2013.

MOHR, Gregory. "The French Camargue-Western.” Crossing Frontiers: Intercultural Perspectives on the Western. Eds. Peter Schulz et al. Marburg: Schüren, 2012, p. 87-95.

MONACO, Paul. A History of American Movies: A Film-by-Film Look at the Art, Craft, and Business of Cinema. Lanham: Scarecrow Press, 2010. 
RAMIREZ BERG, Charles. “The Margin as Center: The Multicultural Dynamics of John Ford's Westers." John Ford Made Westerns: Filming the Legend in the Sound Era. Eds. Gaylyn Studlar, and Matthew Bernstein. Bloomington: Indiana University Press, 2001.

ROWAN, Terry. Motion Pictures from the Fabulous 1950s. Lulu.com, 2015.

RIDING, Alan. “FILM; When French Actors Dare to Look West.” New York Times. May 24, 1998, p. 11. www.nytimes.com/1998/05/24/movies/film-when-french-actors-dare-to-look-west.html. Accessed 21 November 2020.

RIEUPEYROUT, Jean-Louis. Le western : ou, le cinéma américain par excellence. Paris: Les Éditions du Cerf, 1953.

SAINLAUDE, Stève. France and the American Civil War: A Diplomatic History. E-book. The University of Carolina Press, 2019.

SCHARFF, Virginia. "Introduction: Women Envision the West, 1890-1945." Independent Spirits: Women Painters of the American West, 1890-1945. Ed. Patricia Trenton. Berkeley: University of California Press, 1995, p. 1-8.

SCHULZ, Peter, et al. ed. Crossing Frontiers: Intercultural Perspectives on the Western. Marburg: Schüren, 2012.

SCHWARTZ, Vanessa. It's So French! Hollywood, Paris, and the Making of Cosmopolitan Film Culture. Chicago: University of Chicago Press, 2007.

SEDGWICK, John, and Michael Pokorny. An Economic History of Film. Abingdon: Routledge, 2005.

SLOTKIN, Richard. Gunfighter Nation: The Myth of the Frontier in Twentieth-Century America. New York: Atheneum, 1992.

STEGNER, Wallace. Where the Bluebird Sings to the Lemonade Springs: Living and Writing in the West. New York: Penguin, 1992.

STEPENOFF, Bonnie. From French Community to Missouri Town: Ste Geneviève in the Nineteenth Century. Columbia: University of Missouri Press, 2006.

TURNER, Frederick Jackson. “The Rise and Fall of New France.” 1896. Minnesota History, vol. 18, no. 4,1937 , p. 383-398.

WEIL, Kari. Precarious Partners: Horses and their Humans in Nineteenth-Century France. Chicago: University of Chicago Press, 2020.

WILDERMUTH, Mark. Feminism and the Western in Film and Television. Cham: Palgrave, 2018.

YEGENOGLU, Meyda. Colonial Fantasies: Towards a Feminist Reading of Orientalism. Cambridge: Cambridge University Press, 1998.

Filmography

An American in Paris. Dir. V. Minnelli. Written by Alan Jay Lerner. With Gene Kelly (Jerry Mulligan) and Leslie Caron (Lisa Bouvier). MGM, 1951.

Apache Uprising. Dir. R.G. Springsteen. Written by Max Lamb and Harry Sanford. With Rory Calhoun (Jim Walker) and Corinne Calvet (Janice MacKenzie). Paramount, 1965.

Camille. Dir. George Cukor. Written by James Hilton et al. With Greta Garbo (Marguerite Gautier) and Robert Taylor (Armand Duval). MGM, 1936. 
Can-Can. Dir. Walter Lang. Written by Dorothy Kingsley and Charles Lederer. With Shirley MacLaine (Simone Pistache), Louis Jourdan (Philippe Forrestière) and Frank Sinistra (François Durnais). Twentieth Century-Fox, 1960.

Cimarron. Dir. Anthony Mann. Written by Arnold Schulman and Edna Ferber. With Mickie Chouteau (Ruby Red Feather), Glen Ford (Yancey Cravat), Buzz Martin (Cimarron Cravat) and Marie Schell (Sabra Cravat). MGM, 1960.

Fighting Caravans. Dir. Otto Brower and David Burton. Written by Agnes Brand Leahy, Edward Paramore Jr, Keene Thompson. With Gary Cooper (Clint Belmet), Lili Damita (Félice) and Ernest Torrence (Bill Jackson). Paramount, 1931.

Frenchie. Dir. Louis King. Written by Oscar Brodney. With Joel McCrea (Tom Banning) and Shelley Winters (Frenchie). Universal, 1950.

Gigi. Dir. Vincente Minnelli. Written by Alan Jay Lerner. With Leslie Caron (Gigi) and Louis Jourdan (Gaston Lachaille). MGM, 1958.

Heaven's Gate. Dir. Michael Cimino. Written by Michael Cimino. With Isabelle Huppert (Ella Watson), Kris Kristofferson (Jim Averill) and Christopher Walken (Nate Champion). United Artists, 1980

Moulin Rouge. Dir. John Huston. Written by John Huston et al. With José Ferrer (Toulouse-Lautrec) and Zsa Zsa Gabor (Jane Avril). United Artists, 1952.

Monte Walsh. Dir. William Fraker. Written by David Zelag Goodman and Lukas Heller. With Lee Marvin (Monte Walsh), Jeanne Moreau (Martine Bernard), and Jack Palance (Chet Rollins). CCF, 1970.

North to Alaska. Dir. Henry Hathaway. Written by John Lee Mahin, Martin Rackin, Claude Binyon, Wendell Mayes, and Ben Hecht. With Capucine (Michelle Bonet), Fabian (Billy Pratt), Stewart Granger (George Pratt), Ernie Kovacs (Frankie Canon) and John Wayne (Sam McCord). Twentieth Century-Fox, 1960.

North West Mounted Police. Dir. Cecil B. DeMille. Written by Alan Le May, Jesse Lasky Jr, C. Gardner Sullivan. With Gary Cooper (Dusty Rivers), Paulette Goddard (Louvette) and Robbie Preston (Ronnie Logan). Paramount, 1940.

The Far Country. Dir. Anthony Mann. Written by Borden Chase. With Corinne Calvet (Renée Vallon), John McIntire (Judge Gannon), Ruth Roman (Ronda Castle) and James Stewart (Jeff Webster). Universal, 1954.

The Jayhawkers! Dir. Melvin Frank. Written by A. I. Bezzerides, Frank Fenton, and Melvin Frank. With Jeff Chandler (Luke Darcey), Nicole Maurey (Jeanne Dubois) and Fess Parker (Cam Bleeker). Paramount, 1959.

Vera Cruz. Dir. Robert Aldrich. Written by Roland Kibbee and James Webb. With Gary Cooper (Ben Trane), Denise Darcel (Countess Marie Duvarre), Burt Lancaster (Joe Erin), and Sara Montiel (Nina). United Artists, 1954.

Westward the Women. Dir. William Wellman. Written by Charles Schnee. With Denise Darcel (Fifi Danon) and Robert Taylor (Buck). MGM, 1951.

\section{NOTES}

1. Telephone exchange with French producer and director Siham Bel. November 8, 2020. 
2. Image 1074013. Property of MGM. www.mgmmedialicensing.com/PropertyDetails.aspx? propertyID=69776. Accessed 9 December 2020 .

3. A copy of this poster can be found here: en.wikipedia.org/wiki/North_to_Alaska\#/media/ File:North_To_Alaska_1960.jpg. Accessed 21 November 2020.

4. As another illustration of the influence of La Dame aux camélias on the cultural imaginary of the American frontier, Willa Cather's My Antonia (1918) also alludes to a theatrical performance of Dumas Fils' tale as marking the characters Jim Burden and Lena Lingard. "Bibliography: Camille, by Dumas Fils, Alexandre." https://cather.unl.edu/scholarship/reading_bibliography/rbib0307 (accessed December 7, 2020).

5. Indeed, Huppert played the title role in the Franco-Italian film production of Dumas Fils' La Dame aux camélias (Bolognini, 1981) one year after Heaven's Gate was released.

6. According to rug specialist James Stilley, the Aghstafa design, while named after a town of the same name, is thought to be woven in Shirvan, to the Southeast of Aghstafa in the Caucasus. Stilley esteems the rug in Cimarron to be a machine-made replica of an original Aghstafa design. The rug would have been in circulation in the period of the 1890s when the film is set, and as an expensive ornament, is a marker of Sabra Cravat's wealth. James Stilley. Phone call enquiring into the origins of the Cimarron rug. Expert from the "Navajo Rug Appraisal" company, Tucson, Arizona. 5 September 2020.

7. Films in this trend include: The Missing (1993, with Cate Blanchett); The Ballad of Little Jo (1993, with Suzy Amis); The Quick and the Dead (1995, with Sharon Stone); Meek's Cutoff (2010, with Michelle Williams); and Homesman (2014, with Hilary Swank).

\section{ABSTRACTS}

The article explores a corpus of Hollywood Westerns spanning a fifty-year period between 1931 and 1980 in which Frenchwomen are prominent agents on the Western frontier. It suggests that while the American film industry has had a long-standing esteem for French culture, it was during the 1950s that Hollywood began to promote systematically positive representations of Frenchwomen in the Western. It proposes that a genre of "Frenchness Westerns" emerged in the 1950s as a sub-genre of commercially successfully "Frenchness films" (Schwartz 2007) such as An American in Paris (1951) and Gigi (1958). Issuing from a general climate of American post-war Francophilia, Frenchwomen in the "Frenchness Western" are intelligent and daring, even outdoing American male heroes. These women are understood as incarnating an "admirable alterity," and are often compared to indigenous and Mexican women, sometimes aiding the latter in the sphere of interracial romance. These broadly positive representations of the Frenchwoman as agent and potential ally to other women would last until 1980 and Michael Cimino's Heaven's Gate. This essay suggests that the commercial failure of this film seems likely to have had a hand in ending the presence of Frenchwomen in the Hollywood Western-Frenchness becoming synonymous with the financially unviable.

Cet article étudie un corpus de westerns hollywoodiens qui couvre une période de cinquante ans entre 1931 et 1980. Le cinéma américain a toujours estimé la France, perçue comme le pays du glamour, du luxe et des Lumières. Néanmoins, c'est à partir des années 50 que des « westerns à la française » se développent en tant que sous-genre des «films à la française » (Schwartz 2007), genre filmique rentable, tels Un Américain à Paris (1951) et Gigi (1958). Dans un contexte de 
francophilie hollywoodienne, les Françaises dans ces westerns sont présentées comme des femmes intelligentes qui n'ont pas peur du danger, à tel point qu'elles surpassent le héros américain. Incarnant une altérité quasi-racisée et positive ("admirable alterity ), elles sont souvent comparées aux femmes mexicaines et indigènes. Elles promeuvent la possibilité du mariage interracial, habituellement désavoué par le western hollywoodien. Cette représentation positive de la Française, personnage fort de l'Ouest américain et alliée des femmes racisées, durera jusqu'à la sortie de La Porte du paradis de Michael Cimino en 1980. Il est probable que l'échec commercial de ce film ait contribué à la disparition de la Française dans le western hollywoodien.

INDEX

Subjects: Hors-thème

Keywords: admirable alterity, Frenchwomen, Hollywood Western, Frenchness films, Belle Époque, Frenchness Western

Mots-clés: altérité positive, la « Française », western hollywoodien, films à la française, la Belle Époque, western à la française

\section{AUTHOR}

\section{LARA COX}

Cergy Paris Université 